\title{
How Can Micro and Small Enterprises in Sub-Saharan Africa Become More Productive? The Impacts of Experimental Basic Managerial Training
}

\author{
Yukichi Mano, ${ }^{\mathrm{a}}$ Alhassan Iddrisu, ${ }^{\mathrm{b}}$ \\ Yutaka Yoshino, ${ }^{\mathrm{c}}$ and Tetsushi Sonobe ${ }^{\mathrm{d}}$
}

July 18, 2011

${ }^{a}$ Foundation for Advanced Studies on International Development (FASID) and National Graduate Institute of Policy Studies (GRIPS), 7-22-1 Roppongi, Minato-ku, Tokyo 1068677, Japan. Email: yukichi_mano@hotmail.com

${ }^{b}$ The Ministry of Finance and Economic Planning, Ghana. P.O.Box M40, Accra, Ghana. Email: alhassan_370@yahoo.com.

c The World Bank. 1818 H Street, NW, Washington, DC 20433 USA. Email: yyoshino@worldbank.org

${ }^{\mathrm{d}}$ [Corresponding author] Foundation for Advanced Studies on International Development (FASID) and National Graduate Institute of Policy Studies (GRIPS), 7-22-1 Roppongi, Minato-ku, Tokyo 106-8677, Japan. Email: sonobete@grips.ac.jp. Tel: +81-3-54136039 (office), +81-3-3920-1080 (home), Fax: +81-3-5413-0016 


\begin{abstract}
The vast majority of micro and small enterprises (MSEs) in developing countries are located in industrial clusters, and the majority of such clusters have yet to see their growth take off. The performance of MSE clusters is especially low in Sub-Saharan Africa. While existing studies often attribute the poor performance to factors outside firms, problems within firms are seldom scrutinized. In fact, entrepreneurs in these clusters are unfamiliar with standard business practices. Based on a randomized experiment in Ghana, this study demonstrates that basic-level management training improves business practices and performance.
\end{abstract}

Keywords: Africa, Ghana, industrial development, survival clusters, management training, randomized experiment

JEL classification: M31, M41, O14, C93

\title{
Acknowledgement
}

We are grateful for helpful comments from two anonymous referees, John Strauss, Keijiro Otsuka, and the seminar participants at the African Economic Research Consortium and for financial support from the World Bank and the Global Center of Excellence project of the National Graduate Institute for Policy Studies funded by the Ministry of Education, Culture, Sports, Science and Technology, Japan. We thank Paul Kandasamy for editing the paper. The views expressed are ours alone. 


\section{Introduction}

Micro and small enterprises (MSEs) are widely recognized as a major source of employment and income in developing countries. If they grow in size, they would contribute more to economic growth and poverty reduction. In reality, however, their productivity remains low and their sizes remain small (e.g., Mead and Liedholm, 1998, Tybout, 2000). While their low performances may be attributed to the unfavorable circumstances surrounding them, recent empirical studies have identified problems within firms, especially problems regarding management (e.g., Bloom et al., 2010; Bruhn, Karlan, and Schoar, 2010; Sonobe, Akoten, and Otsuka, 2011).

Management has been increasingly recognized as a major determinant of productivity in the recent economics literature (e.g., Syverson, 2011). Bloom and Van Reenen (2007, 2010) collected data on management practices from a number of medium-sized firms in developed and fast-growing countries to establish a close association between management and productivity. Using unique data, Ichinowski, Shaw, and Prennushi (1997), Lazear (2000), and Bertrand and Schoar (2003), among others, show that human resource management and top executives' management style are important determinants of productivity in the U.S.

To establish causality more directly, Karlan and Valdivia (2011), Drexler, Fischer, and Schoar (2010), and Bruhn, Karlan, and Schoar (2010) have carried out randomized control trials in which management training or a consulting service is provided for MSEs in their study sites in Latin America. The most clear-cut result of these experiments is that rudimentary, as opposed to standard, management training improves business practices. This indicates that many MSE entrepreneurs in developing countries know little about management. A somewhat discouraging result of the experiments, however, is that the 
impacts of the management training and consulting on sales and profits are economically large but are statistically weak.

This paper attempts to extend this line of research by using experimental data gathered before and after a management training program offered to MSEs in Africa. In our view, MSE entrepreneurs' lack of management knowledge has a great deal to do with their locational choices. Although the existing studies do not specify where their subjects are located, we suspect that they are located in industrial clusters because the vast majority of MSEs in developing countries are located in such clusters, defined as the geographic concentration of a number of firms producing similar and related products. Industrial clusters are spontaneously formed in a wide range of countries and sectors because of the benefits of localization economies (Nadvi and Schmitz, 1994). As documented in recent case studies, localization economies in clusters allow new entrants with little managerial and financial capital to start businesses (e.g., Schmitz and Nadvi, 1999; Ruan and Zhang, 2009; Sonobe and Otsuka, 2006, 2011). Moreover, like human capital, managerial capital may well be underinvested in, and many entrepreneurs may be unaware of the value of acquiring managerial capital (Bloom et al., 2010). Thus, it is not surprising that MSE entrepreneurs lack basic knowledge and skills regarding management. As a case study by Iddrisu et al. (2011) indicates, however, it is likely that many such entrepreneurs are now willing to learn about management because the profitability of their businesses have been declining due to intensified competition with an increasing number of new entrants producing similar products and the massive import of cheap products from newly industrialized economies.

This study provides an elementary management training program for MSE entrepreneurs in an industrial cluster. It examines whether the entrepreneurs are willing to learn about management and to what extent the training improves the performance of their 
businesses. We find that the vast majority of the entrepreneurs invited to the training program attended the training sessions in earnest, and that many adopted the management practices taught in the program. None of the participants were closed down, whereas nearly ten percent of the enterprises in the control group were closed down after the training. The difference in survival rate between the treatment and control groups is statistically significant. As with the existing studies, however, we find that the estimated average effects of the training on accounting-based measures of performance, such as sales and profits, are economically large but statistically insignificant. In the experiment carried out by Bruhn, Karlan, and Schoar (2010), the provision of consulting services to MSEs was expected to improve the clients' business performances, but statistically, the effects were only marginally significant. The authors attribute this result to noisy data and the relatively small sample size. In the case of our experiment, the training increased the percentage of participants adopting the recommended practices from near zero to 50 percent; however, the rest of the participants did not even attempt to adopt the practices. Such variation among the participants seems to be a cause of the statistically weak effect of the training on the participants' business performance. The results of analysis suggest that such variation can be reduced if participants are taught how to motivate workers to adopt new practices.

The next section reviews the studies of industrial clusters in developing countries and clarifies the questions to be addressed in this paper. Section 3 describes the sampling scheme and the training design, and Section 4 presents the basic statistics. After specifying the regression models, Section 5 reports the estimation results and discusses the directions of possible estimation biases due to attrition, spillovers, market stealing, and psychological effects. Finally, Section 6 discusses the implications for future research. 


\section{Location and management of MSEs}

Casual observations suggest that the vast majority of MSEs in developing countries are located in industrial clusters including small clusters of furniture makers along roadsides, garment markets in which tailors are producing and selling clothes, and the like. The benefits of localization economies, which attract MSEs to industrial clusters, include favorable access to market information, low transaction costs due to easy monitoring and the effective functioning of the reputation mechanism among firms located near each other, and the resulting development of the division of labor among manufacturers and between manufacturers and traders (Sonobe and Otsuka, 2006).

Case studies of industrial clusters in Asia, Latin America, and Africa suggest that clusters in different industries in different countries follow the same development path until they reach a certain phase and then the path bifurcates (e.g., Schmitz and Nadvi, 1999; Sonobe and Otsuka, 2006, 2011). An industry is born in a developing country when a cheap imitated substitute of an imported product wins popularity in a local market. An industrial cluster is formed as an increasing number of new firms begin producing imitated products near the pioneer's location. As new firms enter the cluster, the division of labor is developed in the cluster. Each firm specializes in a narrow segment of a value chain, with only a narrow range of skills and a small initial investment (Ruan and Zhang, 2009).

Thus, a cluster attracts a swarm of new entrants, and the increased scale of the cluster reinforces the localization economies. Sonobe and Otsuka $(2006,2011)$ refer to this phase of industrial development as the quantity expansion phase since the expansion of the cluster is based on the new entry of imitators without any qualitative improvement in the products or the production processes. In this phase, owners do not keep records of transactions or inventory (e.g., de Mel, McKenzie, and Woodruff, 2009), and they fail to separate financing 
for their businesses with that of their own households. Even casual observers notice that in such disorganized workshops, owners and workers waste time looking for necessary tools and materials on a daily basis. Although these owners are not managers in the real sense of the term, they are still able to maintain their small businesses. Because every transaction and activity takes place in full view of the owners, small businesses are easy to operate.

The increase in the supply of homogeneous low-quality products due to the proliferation of imitative firms will sooner or later saturate the local market, resulting in the decline of the product price and the profitability of producing such low-quality products. The declining profitability induces entrepreneurs to attempt product quality improvements. According to case studies, successful quality improvement involves the establishment of brand names, the development of new marketing channels and the introduction of a standard management system with stricter control of product quality and work effort, and the establishment of trust-based long-term subcontracting relationships with parts-suppliers (Sonobe and Otsuka, 2006). For such multifaceted improvements, it is important to gain knowledge about technology and management from outside the cluster and to take advantage of the pool of human resources within the cluster, such as traders, engineers, and partssuppliers. With the progression of quality improvement, successful firms become larger and the total number of firms decreases through exits and mergers of inefficient firms.

If a cluster fails in quality improvement, however, profitability will continue to decline until new entry ceases. Firms will continue to produce the same low-quality products, and their ways of running businesses will remain far from systematic and efficient. When local economies were closed to international trade, firms could survive without difficulty. In the era of globalization, however, firms face competition from foreign producers who constantly improve their products or reduce costs. The literature on industrial clusters reports several 
cases in which negative external shocks turned out to be blessings in disguise in the sense that they triggered multifaceted improvements within clusters. ${ }^{1}$ In many other clusters, however, negative external shocks have worsened the downward trend in profitability, and firms are struggling to survive (e.g., Altenburg and Meyer-Stamer, 1999; Kennedy, 1999; McCormick, 1999; Akoten and Otsuka, 2007).

Thus, a cluster may either enter the quality improvement phase or stay as a survival cluster. A major hypothesis is that among the important determinants of a cluster's fate is the management knowledge of the entrepreneurs in the cluster. This study examines to what extent basic management training can improve the business practices and performance of firms in a survival cluster. The evaluation of the full effect of the training will require several rounds of follow-up surveys. At this stage of research where we have completed only the first post-training survey, we can only analyze the short-run effects.

According to the literature on technology diffusion, the same technology is adopted by different adopters several years apart, and a major explanation for such a phenomenon is that different adopters put different values on the new technology (e.g., Hall and Khan 2003). Likewise, management training participants will be heterogeneous in both incentive and in the ability to put the knowledge they gain from the training into practice. Moreover, their business performance will be subject to idiosyncratic shocks. Thus, we expect that the effect of the training on performance will vary considerably among the participants.

If management training proves to be useful for at least some participants, the question arises as to whether the benefit is large enough to justify the cost of the training. For this reason, we focus on the short-run private benefit because the benefits and losses for nonparticipants, neighbors, and consumers (i.e., social welfare) are practically impossible to capture in the data. In short, this paper examines the effects of a managerial training 
program on the participating entrepreneurs' business practices and performance and compares the cost and private benefit of such a program.

\section{Surveys and training program}

Our study site is Suame Magazine, located in Kumasi, the second largest city in Ghana. Kumasi is a junction of artery roads connecting major coastal cities and major inland cities including Ouagadougou, the capital city of Burkina Faso. ${ }^{2}$ Suame Magazine is known in West Africa as a large cluster of garage mechanics, but it is also a cluster of metalwork enterprises producing a variety of metal products, such as bolts and nuts, corn mill machines, threshing machines, and cash safes. $^{3}$ The garage cluster has had a long period of quantitative expansion because the demand for car repair services has increased dramatically. As the garage cluster expanded, scrap metal became increasingly available, helping the expansion of the metalwork cluster.

[Table 1 should be inserted here.]

We conducted a survey of metalwork entrepreneurs in early 2005. At that time, most masters, whether garage mechanics or metalwork entrepreneurs, were members of the Suame branch of the Ghana National Association of Garages (GNAG). As shown in Table 1, the number of members in 2003 exceeded 10,000, of which more than 1,000 were metalwork entrepreneurs. The number of metalwork entrepreneurs does not seem to have increased since then. As will be shown in Table 3 below, the profitability in this cluster began decreasing clearly in the early 2000s. The metalwork cluster in Suame Magazine was a typical survival cluster except for the extraordinarily large size of the annexed garage 
cluster. For the survey, we selected 167 metalwork entrepreneurs randomly from the GNAG member list. Their data on educational and occupational backgrounds, production and costs, marketing channels, and investments were gathered by visiting each of them (Iddrisu, 2007).

The training program was implemented for three weeks from the middle of November, 2007. ${ }^{4}$ The program consisted of three modules of classroom training: Module 1 on entrepreneurship, business planning, and marketing; Module 2 on production management and quality management; and Module 3 on record keeping and costing. ${ }^{5}$ Each module lasted for five weekdays, 2.5 hours per day in the evening. The venue was the Suame Branch of the National Vocational Training Institute (NVTI) in the cluster, so that busy entrepreneurs could attend the classes after work.

The instructors were three Ghanaian consultants with extensive experience. They were selected through an international competitive tender, based both on the cost and quality of their submitted proposal, following the World Bank's procurement guidelines. ${ }^{6}$ They spoke the local language, Twi, and thus communicated smoothly with the participants. Modules 1 and 3 were based on the textbooks of the improve-your-business (IYB) and startyour-business (SYB) training program developed by the International Labor Organization (ILO). IYB and SYB are implemented as standard business training modules in many developing countries. Our instructors emphasized the importance of identifying good customers, separating business and household finances, keeping records, and other very basic practices. Drexler, Fischer, and Schoar (2010) find that a "simplified, rule-of-thumb" training of accounting has significant impacts on business results. The third module of our program involved exactly such basic training on record keeping. The training hours were allocated almost evenly to the instructors' lectures and to group work and debates. 
The contents of Module 2 were not as standard as those of Modules 1 and 3, but they were as easy to understand. This module began with an explanation of the concepts of productivity and quality, which was followed by discussions regarding the difference between value adding and non-value adding activities, and the workplace housekeeping method called $5 \mathrm{~S} .{ }^{7}$ The instructor also discussed an inexpensive approach to improving productivity and quality called KAIZEN.

Before selecting the entrepreneurs to invite to the training program, we were advised by an adult education expert that the number of participants in a classroom should be 60 or less. Since we had already committed ourselves to inviting seven entrepreneurs who had assisted in our study, we selected 53 other entrepreneurs randomly from the sample of the baseline survey and trained them together in the same classroom. The seven pre-selected participants will be treated with special attention in the analysis below.

When we invited the 60 entrepreneurs to the training program, we explained that the program was not related to any financial assistance to them. Nonetheless, many of the participants expected to receive low-interest credits, according to our informants. They were disappointed to learn that such credits would not be extended to them, but they continued to attend class and became increasingly enthusiastic about learning more about management toward the end of the program. ${ }^{8}$

The training program cost about 40,000 US dollars, which included the hiring cost of the instructors, the cost of teaching material production, the cost of the instructors' travel from Accra to Kumasi and accommodation expenses, and the cost of renting the venue. The cost of selecting the instructors and the researchers' travel cost were not included in this amount. The venue cost was very low because we were able to use the NVTI classroom for 
an insignificant amount. If the total cost is divided by the number of the participants, the training cost per person will be about 740 US dollars for the 15 days.

A follow-up survey was conducted in November 2008, i.e., about a year after the training sessions were completed. We attempted to visit the 167 firms in the sample of the baseline survey and obtained data of 139 firms. We found ten firms had closed down. An encouraging fact is that none of the participants had closed down, which suggests a favorable effect of the training on enterprise survival. We could not obtain data of 18 other sample firms. One of them refused to cooperate with our survey. We could meet neither the entrepreneurs nor their workers at the remaining 17 firms and could not be sure whether these firms were temporarily or permanently closed. ${ }^{9}$ These 18 attritors are also in the control group; that is, they had not been invited to the training program. We will discuss possible estimation biases due to the attrition in Section 5.

During the training program, we learned that most of the foundry men in both the treatment and control groups had received technical training from an aid agency in the same year. Another problem was that after our training program, several entrepreneurs in our sample were evicted from a prime location which they had occupied without permission. Needless to say, the eviction had a severe impact on their businesses. In the analysis below, we use both the larger sample consisting of 139 firms (plus ten closed-down firms) and the smaller sample consisting of 113 firms (plus six closed-down firms) other than the foundries, the evicted firms, and the pre-selected participants.

\section{Basic statistics}

In the smaller sample, the treatment group consists of 47 entrepreneurs and the control group consists of 66 entrepreneurs, as shown in Table 2. By the treatment group, we mean 
those entrepreneurs invited to attend the training program. In the treatment group, there are six refusers, who did not attend the training at all or only attended the first two days. The remaining members in the treatment group are called participants. The participants attended 14.1 days on average, and the majority recorded perfect attendance. The high rates of participation and attendance are consistent with our hypothesis that entrepreneurs in survival clusters are willing to learn management practices.

[Table 2 here.]

The treatment group and the control group share similar background attributes. A typical entrepreneur is male, about 45 years old, from the Ashanti region, where the cluster is located, went to school for a little more than 10 years, learned the skill of the trade as an apprentice from a master of either fabrication or machining for three to four years, and has been operating his own business for nearly 14 years. Fabricators are basically welders, whereas machinists are basically lathe turners. Many workshops have both fabricators and machinists because their activities are complementary. We classify the entrepreneurs in the smaller sample into these two types - fabricators and machinists - based on the original line of work that they were engaged in when they started their businesses.

Table 2 shows that the refusers tended to be older than the participants. Older entrepreneurs may have had greater time costs or lower expected benefits from the training than younger entrepreneurs. Another characteristic of the refusers is that none of them are from outside the Ashanti region. Local inhabitants would have greater involvement in extended family functions, community functions, and sideline businesses than those from other regions. If this was the case, their opportunity costs would be higher. 
[Table 3 here.]

Table 3 reports the data on the adoption of recommended practices and three accounting-based indicators of business performance. The data on the situations in 2000 and 2002 are recall data collected in 2004. The left side of the table shows the percentages of the entrepreneurs who visited customers periodically, kept records, and routinely analyzed the records in the specified year. Visiting customers is not a common activity in this cluster, and the majority of the sample firms do not keep records. Even if records are kept, they are seldom reviewed or analyzed. The data on the adoption of production management practices are not shown in the table because we could not obtain useful data. This is because few non-participants understood our questions about production management.

After the training, the percentage of firms in the control group keeping records increased by only 6 percentage points whereas the increase was 36 points in the treatment group. Similarly, the adoption rates of the other two practices (i.e., keeping and analyzing records) increased much more in the treatment group than in the control group. These results indicate that the training had strong impacts on the adoption of the recommended practices. Another noteworthy point is that well over one third of the treatment group firms did not adopt the recommended practices. The variance of each adoption variable within the treatment group increased after the training because the variance of the dummy variable increases as the mean approaches 0.5 .

The right side of Table 3 reports the data on annual sales revenue, value added, and gross profit by treatment status. Gross profit here is defined as sales revenue minus material cost and labor cost. Because the majority of firms did not keep records, we 
estimated these financial variables by asking each entrepreneur about the number of pieces sold and their prices by product type, material inputs and material prices, payments to subcontractors, and payments to workers and apprentices. We checked that the estimate of gross profit was consistent with the entrepreneur's earnings, investment, living expenses, purchase of durable goods, and so on. ${ }^{10}$ Written records, whenever available, were used deliberately, taking into account that each entrepreneur might have his own unique concept of costs and that his calculation might be incorrect.

The trend of declining profitability is visible in Table 3. Some respondents said definitely that this trend was set by the proliferation of competitors within the cluster, and that it was being worsened by massive imports of similar products from Asia and increasing competition with similar clusters in the country. Decreases in sales, and gross profits after the training were somewhat smaller for the treatment group than for the control group. These differences in the mean values are small but suggest that the training had favorable effects.

[Table 4 here.]

The training seems to have impacts on equipment investment as well. Note that Table 4 shows investment amounts in GHS, whereas Table 3 shows the sales, value added, and gross profit in 1,000 GHS, which was almost equivalent to 1,000 US dollars in 2008 . The median investment amount in each year is zero, i.e., the majority in each year undertakes no equipment investment. Although the average of the investments by the fabricator control group is relatively high in 2008, the magnitude is not impressive for equipment investment even by the standard in the cluster. Sizable investments were 
undertaken by three machinist participants, who purchased machine tools. As a result, the difference in investment between the treatment and control groups of machinists became significant at the 5 percent level after the training, as shown in Table 4 . Another sizable investment was undertaken by a fabricator participant, who relocated his workshop to a better conditioned site outside the cluster and installed new machines. This is not reflected in the data because it took place a few months after the follow-up survey.

\section{Estimation}

\section{5-1 Specification}

In this section, we estimate the average effects of the training on the participants' survival, their business performances, and their adoption of recommended business practices. Let $Y_{1 i}$ be the outcome that firm $i$ will have if its entrepreneur participates in the training, and let $Y_{0 i}$ be the outcome that he will have if he does not receive the training. If $D_{i}$ is a dummy variable that is equal to 1 for participants and 0 for non-participants, the average effect of the training on the participants may be given by $E\left(Y_{1 i} \mid D_{i}=1\right)-E\left(Y_{0 i} \mid D_{i}=1\right)$ or $E\left(Y_{1 i}-Y_{0 i} \mid D_{i}=1\right)$. By definition, $E\left(Y_{0 i} \mid D_{i}=1\right)$ is hypothetical and unobservable, but it will be equal to an observable value, $E\left(Y_{0 i} \mid D_{i}=0\right)$, if the participants are randomly selected. Note, however, that although invitation was randomized, participation was not, and that the invited participants decided themselves whether to participate.

To cope with self-selection biases and to take advantage of the randomization in the invitation, we resort to the framework of the local average treatment effect (LATE). In this framework, a key role is played by the dummy variable $Z_{i}$ that is 1 if entrepreneur $i$ was invited to the training and 0 otherwise. Obviously, $D$ and $Z$ are closely associated because only the invited entrepreneurs could participate in the training. Let $D_{1 i}$ and $D_{0 i}$ be the 
values of $D_{i}$ when $Z_{i}=1$ and when $Z_{i}=0$, respectively. LATE is the average treatment effect on those whose treatment status is affected by random assignment (i.e., invitation in our case) and defined by

$$
\mathrm{LATE}=E\left[Y_{1 i}-Y_{0 i} \mid D_{1 i} \neq D_{0 i}\right] .
$$

Imbens and Angrist (1994) show that if $Y_{1 i}, Y_{0 i}, D_{1 i}$, and $D_{0 i}$, are independent of $Z_{i}$ and if $D_{1 i}$ $\geq D_{0 i}$, for all $i$ (monotonicity),

$$
\mathrm{LATE}=\operatorname{Cov}\left(Y_{i}, Z_{i}\right) / \operatorname{Cov}\left(D_{i}, Z_{i}\right) .
$$

where $Y_{i}$ is the outcome actually observed for firm $i$.

Since all the participants in our program were invited, $D_{0 i}$ is 0 and $D_{1 i}$ is either 0 or 1 . Those invited entrepreneurs with $D_{1 i}=0$ are the refusers and those with $D_{1 i}=1$ are the participants. Thus, $D_{1 i} \neq D_{0 i}$ in equation (1) means that entrepreneur $i$ will participate in the training if invited, and LATE in our case is equivalent to $E\left[Y_{1 i}-Y_{0 i} \mid D_{i}=1\right]$, i.e., the average training effect on the participants. It is easy to show that the monotonicity condition is satisfied in our case. Equation (2) implies that LATE can be estimated as coefficient $\beta$ in a regression model, $Y_{i}=\alpha+\beta D_{i}+\varepsilon_{i}$, by using $Z_{i}$ as an instrumental variable (IV). Following the lead of Frison and Pocock (1992) and McKenzie (2011), we use the Analysis of Covariance (ANCOVA) regression, which may be written

$$
Y_{i A}=\alpha+\beta D_{i}+\theta Y_{i B}+X_{i B} \gamma+\varepsilon_{i},
$$


where $Y_{i A}$ is the post-training outcome, $Y_{i B}$ is the average of the outcomes in the pre-training years, namely 2000,2002 , and 2004 , and $X_{i B}$ is a vector of the entrepreneur's background attributes measured in year 2004, which are almost all time invariant. The use of random assignment, $Z_{i}$, as an IV allows us to obtain a consistent estimate of $\beta$.

\section{5-2. Estimation results}

In the estimation of equation (3), the first-stage regression has $D_{i}$ on the left-hand side and the instrument, $Z_{i}$, and the controls $X_{i B}$ on the right-hand side. The qualitative results of the first-stage regression are the same regardless of whether the larger or smaller sample is used and can be summarized briefly. Since $D_{i}$ and $Z_{i}$ are closely correlated, $Z_{i}$ has a highly significant coefficient. Consistent with Table 2, the age variable and the Ashanti dummy variable have negative and significant coefficients. No other variables have significant coefficients in the first-stage regressions.

The second-stage regression results are reported in Tables 5 to 8 . Table 5 shows the results concerning enterprise survival. After the training program, two foundry men, four fabricators, and four machinists stopped operation and exited the cluster. It is remarkable that they all belonged to the control group and that none of the training participants stopped operation. This means that we cannot employ the probit model. Instead, we employ the linear probability model to check the statistical significance of the coefficient on the instrumented $D_{i}$. In this model, $Y_{i A}$ is a dummy variable equal to unity if the firm was operating at the follow-up survey and zero otherwise, and the lagged dependent variable $Y_{i B}$ on the right-hand side of equation (3) is unity for all $i$.

[Table 5 here.] 
The results of such a two-stage regression are qualitatively the same regardless of whether the larger or the smaller sample is used. Table 5 reports the results obtained by using the smaller sample. The estimated effect is positive and significant at the one percent level in column (i) and at the five percent level in columns (ii) to (v). Participation in the training program increases the probability of survival by 8 or 9 percentage points. Although not reported in the table, the estimate of the survival effect is greater and has a higher significance level if the larger sample is used.

Columns (ii) to (v) include as controls the dummy variables indicating whether the firm had adopted the recommended business practices even before the training. The estimation results indicate that the firms that had kept records of transactions even before the training program were more likely to survive than other firms. Columns (iii) to (v) include one of the accounting-based indicators of business performance before the training program, but none of these indicators have significant coefficients. In every column, the entrepreneur's schooling has a positive and marginally significant coefficient. A possible interpretation is that schooling increases outside opportunities for entrepreneurs, even though we do not have any evidence supporting this interpretation.

[Table 6 here.]

Table 6 reports the estimated effects of the training on the participants' adoption of the recommended practices and their performance indicators. These estimates are obtained by using the larger sample without taking into account the closing down and other attrition cases. The dependent variables in the first three columns are the dummies indicating 
whether the recommended practices were adopted. In the last three columns, the dependent variables are sales, value added, and gross profit, which are not logarithmic but in 1,000 GHS units. The estimated average effects of the training on the participants' adoption of the three recommended practices are positive and highly significant as shown in the first three columns. Note, however, that these effects are not homogeneous because one third to half of the participants did not adopt these practices as shown in Table 3.

The estimated coefficients on the instrumented $D_{i}$ are positive but insignificant as shown in the last three columns. These estimated coefficients are not large compared with the large standard errors, but their economic magnitudes are not small. For example, this coefficient in the gross profit equation is the estimate of $E\left(\pi_{1 i}-\pi_{0 i} \mid D_{i}=1\right)$, which can be viewed as the pecuniary private benefit of the training per participant in the first year following the training. The hypothetical gross profit $\pi_{0 i}$ can be regarded as the opportunity cost. If the effect is felt in the years ahead, $E\left(\pi_{1 i}-\pi_{0 i} \mid D_{i}=1\right)$ is only a part of the private benefit. In contrast, the training cost of 740 USD per participant is a one-time cost. The estimated one-year benefit of 4,230 GHS is very large compared with this cost. However, this estimate is statistically insignificant.

The larger sample, which is used in producing Table 6, includes the entrepreneurs who attended another training program which included similar training contents and those evicted entrepreneurs whose businesses suffered great damage. Although these entrepreneurs are more or less evenly distributed across the treatment and control groups, their inclusion in the sample may lead to an underestimate of the effect of the training on business performance. Suppose that participation in our training program and that in another training program are equally effective in improving business performance. Suppose further that these two programs are largely substitutes rather than complements, and, hence, the effect of 
participation in both programs on performance is not much stronger than the effect of participation in either one. If this is the case, the inclusion of the entrepreneurs who participated in another program in the sample will weaken the estimated effect of our training program. Similarly, if the eviction nullified the effects of the training, we would underestimate the effects by including the evicted entrepreneurs in the sample.

[Table 7 here.]

If such is the case, the exclusion of the entrepreneurs who participated in another training program and the evicted entrepreneurs will lead to greater estimates of the training effects. We thus used the smaller sample to estimate the same model as above and report the estimated effects of the training on the adoption of the recommended practices and performance indicators in the first row of Table 7. Except for column (iii), the coefficient on the instrumented $D_{i}$ is greater in Table 7 than in Table 6. While the two tables do not differ much in the estimated effects on the adoption of the recommended practices, they do in the estimated effects on the accounting-based performance indicators. The estimated effects on value added and gross profit are statistically significant in Table 7 . The estimated coefficient on gross profit indicates that the private benefit of the training in the first year is $13,400 \mathrm{GHS}$, which is about 18 times the training cost.

While the effects on sales revenue and gross profit are insignificant and significant, respectively, in Table 7, Berge et al. (2011) find that a similar business training program increased the sales revenue but not the profit margin. A possible explanation why our training program had a stronger effect on gross profit than on sales revenue is that our training put emphasis on improvements in production management, especially the reduction 
of waste. The training program studied by Berge et al. did not have a module on production management. Another possible explanation is that while all the participants in our training program were manufacturers, the majority of the participants in the training program studied by Berge et al. were engaged in commerce.

\section{5-3. Heterogeneous effects}

How heterogeneous are the treatment effects? We examined the heterogeneous effects by inserting interaction terms of times the variables representing the entrepreneur's background attributes, such as age and education, in turn. We find a significant difference in treatment effects between different groups only in the following three cases (see the second panel of Table 7). When $D_{i}$ is interacted with the machinist dummy, the treatment effect on record keeping turns out to be weaker for the machinists than for the fabricators, even though the difference in the treatment effect is only marginally significant. Probably, this result reflects the fact that record keeping was much more common among the machinists than among the fabricators. When $D_{i}$ is interacted with age, it is found that the treatment effect on the record analysis outcome is slightly weaker for older entrepreneurs than for younger entrepreneurs. This is probably because less experienced young entrepreneurs had not noticed the usefulness of analyzing transaction records.

Clearer heterogeneous effects are found when the $D_{i}$ dummy variable is interacted with the years of schooling. More highly educated participants were more likely to begin visiting customers and keeping and analyzing records. Probably, educated participants would tend to begin keeping the names and mobile phone numbers of customers so that they could visit the customers, and their math skills would help them keep and analyze transaction records. However, the effects of the training on the accounting-based measures 
of business performance are lower for more educated participants. Since more highly educated entrepreneurs tend to employ and train a greater number of workers and apprentices, these results suggest that an improvement in business performance is more difficult for larger firms than for smaller firms. Although the training program introduced the participants to KAIZEN, which provides useful clues as to how workers can be motivated to adopt new practices, there was not enough time to explain such details.

\section{5-4. Attrition bias and bounds tests}

Attrition is one of the sources of potential estimation bias. As noted above, ten sample firms closed down. Among the other 18 attritors, one refused to cooperate with our survey, 11 were found operating when we visited them a year later, and six were missing even on our revisit. Thus, the 11 firms were temporarily closed, and the six firms might be permanently closed. Although these 18 attritors seem to have performed poorly, we examined what if these attritors were the most successful firms or if they were slightly more successful than the average, by using the bounding approach of Karlan and Valdivia (2011) to construct lower bounds for the treatment effect.

[Table 8 here.]

The lower (upper) bound for the treatment effect shown in the first panel entitled Approach I in Table 8 is developed by assuming that the attritors' outcomes were equal to the outcome of the most (least) successful firm in the observed control group. It is remarkable that even the lower bounds on the treatment effects on record keeping and record analysis are positive and significant. While the lower bounds on the treatment effects on 
the accounting-based measures of business performance are negative and insignificant. In Approaches II and III, the lower (and upper bounds) are computed under more modest assumptions that the attritors' outcomes are the mean plus (and minus) 0.25 standard deviations and 0.1 standard deviations, respectively, of the observed control distribution. In these approaches, even the lower bounds on the treatment effects on the adoption of the recommended practices are highly significant, and those on business performance are positive and marginally significant.

\section{5-6. Spillovers and market stealing}

In industrial clusters, knowledge spills over quickly. According to our respondents, the training participants talked to other entrepreneurs about their impressions of the program, the instructors, and the outline of the training contents. Knowledge spillovers would reduce the estimate of the training impacts as spillovers improve the business results of the control group, which in turn reduces $\operatorname{Cov}\left(Y_{i}, Z_{i}\right)$ in equation (2).

As Bloom et al. (2007) point out, firms' productivity improvement can affect other firms' performance through market stealing as well as spillovers. The first module of our training program encouraged the participants to be proactive in getting new customers. A few participants told us that soon after the training, they began issuing invoices and receipts on which their mobile phone numbers were printed, and they believed that the invoices and receipts had doubled their sales compared with the previous year. Their sales may have increased at the cost of other firms' sales. The market-stealing effect would overstate the training effects on the participants by worsening the business results of the control group.

The impacts of spillovers and market stealing may or may not be strong. Knowledge does not affect business results if it is not put into practice. As shown in Table 3, the 
control group's adoption rates in 2008 increased only slightly in contrast to the significant increases among the treatment group in the same year. Furthermore, not all the adopters would successfully assimilate the practices that they adopted. Market stealing by a participant would worsen the business results of the other participants as well as the nonparticipants, and these negative effects could cancel each other out. The assessment of the impacts of spillovers and market stealing is deferred to future follow-up surveys.

\section{5-7. Psychological effects}

The increases in the control group's adoption rates in 2008 may also be attributed to a psychological effect. It is only human to show that one is doing well, even if this involves some pretense. In the follow-up survey, some entrepreneurs may have exaggerated how well their firms were doing. Moreover, the control group may have been loath to admit that they had failed to benefit from the training program. It is not difficult to imagine that some of them exaggerated not just the adoption of the recommended practices but also their business results. The follow-up survey data on the participants may have a similar problem. The participants may have been tempted to please us by exaggerating their benefits from the training program. Such a problem may not be very serious in our case, however, since we visited the entrepreneurs at their workshops to conduct the survey, observed their products, and asked them to show us their business records, if they kept any.

\section{Conclusion}

As in the rest of the world, there are a number of industrial clusters in Sub-Saharan Africa, but unlike clusters in other regions, these clusters have not yet achieved successful industrial development. Their low performances have been attributed exclusively to factors 
outside firms, such as poor infrastructure and unfavorable governance. By contrast, problems within firms have seldom been scrutinized. Based on a randomized controlled experiment in Ghana, this study demonstrates that entrepreneurs in a survival cluster are unfamiliar with the business practices which are standard in developed countries and some other developing countries. It also indicates that participation in a rudimentary management training program improves the business practices and results of the participants with considerably varying degrees of success. Although we should be cautious about generalization, these results are highly consistent with the results of earlier studies in Latin America. It seems safe to conclude that entrepreneurs in developing countries can improve the productivity of their MSEs by learning management techniques.

In earlier studies, the estimated training effects were economically large but statistically insignificant or only marginally significant. Our results suggest that such weak estimates come from large variations among the participants in terms of their own inherent abilities and education levels and their workers abilities and motivation. Probably, entrepreneurs' managerial abilities are more difficult to improve than workers' skills. Unlike vocational training, a management training program may improve the managerial abilities of only a few participants. Nonetheless, it may be worth providing from the social welfare point of view. This is because the quality improvement phase of industrial development is led by a few innovative entrepreneurs, and their success contributes to the overall social welfare through increasing awareness of the value of training as well as imitation by many other entrepreneurs.

The results of this paper warrant considerable further research. The longer-term training effects should be examined in future. Our conjecture is that only a small number of participants will continue to improve their business performance based on the knowledge 
acquired in the training. Another direction to explore is to provide advanced training. By providing elementary training, we have confirmed that entrepreneurs in the survival phase know little about management. Advanced training will allow us to explore what factors help industrial clusters enter the quality improvement phase successfully. 


\section{Notes}

1. Examples include a surgical instrument cluster in Pakistan (Nadvi, 1999), a garment cluster in India (Tewari, 1999), and shoe clusters in Brazil (Schmitz, 1999), and Ethiopia (Sonobe, Akoten, and Otsuka, 2009).

2. This area used to be the site of an army depot called Magazine during the colonial times. The name Magazine has been adopted by similar engineering clusters in the northern part of Ghana, whereas those in the southern part are called Kokompes.

3. McCormick (1999) provides a bird's-eye view of this cluster.

4. The training program was funded by the Government of Japan through its Policy and Human Resource Development (PHRD) trust fund at the World Bank.

5. The program was modeled on the "Business Course" provided by the Japan International Cooperation Agency (JICA) in eight transition economies; Cambodia, Kazakhstan, Laos, Mongolia, Ukraine, Uzbekistan, Kyrgyzstan, Vietnam.

6. The lead consultant was an SYB master trainer. The instructor in charge of Module 2 had received training in metalwork in Japan and was familiar with KAIZEN.

7. $5 \mathrm{~S}$ is named after the corresponding Japanese words whose Romanized forms begin with the letter s. Their English counterparts also begin with s; that is, sorting, setting in order, systematic cleaning, systematizing, and self-discipline.

8. Including the pre-selected participants, the majority of the participants recorded perfect attendance. At the end of the program, the participants evaluated the program as follows: 98 percent found the program very important to their business, 94 percent had learnt very much, and 96 percent were satisfied with the program.

9. When we revisited the study site a year later, we found that 11 of these 17 firms had been temporarily closed at the time of our survey and then resumed the same businesses. 
10. We usually began by asking about the price of each product and the output in a busy month and in a slack month, together with a question about when the workshop was busiest. If the respondent was unsure, we changed tack and asked, for example, how many units of a product were produced from one unit of a material, and how often and how many units of the material were purchased in a busy month and in a slack month. 


\section{References}

Akoten, J.E. \& Otsuka, K. (2007). From tailors to mini-manufacturers: The role of traders in the transformation of garment enterprises in Nairobi. Journal of African Economies, 16 (4), 564-95.

Altenburg T. \& Meyer-Stamer, J. (1999). How to promote clusters: Policy experiences from Latin America. $\quad$ World Development, 27 (9), 1693-1713.

Berge, L. I. O., Bjorvatn, K. \& Tungodden, B. (2011). Human and Financial Capital for Microenterprise Development: Evidence from a Field and Lab Experiment. NHH Deptartment of Economics Discussion Paper No. 1/2011.

Bertrand, M. \& Schoar, A.S. (2003). Managing with Style: The Effect of Managers on Firm Policies. Quarterly Journal of Economics, 118 (4), 1169-1208.

Bloom, N., Mahajan, A., McKenzie, D. \& Roberts, J. (2010). Why Do Firms in Developing Countries Have Low Productivity? American Economic Review: Papers \& Proceedings, $100(2), 619-23$.

Bloom, N., Schankerman, M., \& Van Reenen, J. (2007). Identifying Technology Spillovers and Product Market Rivalry. National Bureau of Economic Research Working Paper 13060.

Bloom, N. \& Van Reenen, J. (2007). Measuring and explaining management practices across firms and countries. Quarterly Journal of Economics, 122 (4), 1351-1408.

Bloom, N. \& Van Reenen, J. (2010). Why do management practices differ across firms and countries? Journal of Economic Perspectives, 24 (1), 203-224.

Bruhn, M., Karlan, D. \& Schoar, A. (2010). What Capital is Missing in Developing Countries? American Economic Review: Papers \& Proceedings, 100 (2), 629-33.

de Mel, S., D., Mckenzie, J. \& Woodruff, C. (2009). Measuring microenterprise profits: Must we ask how the sausage is made? Journal of Development Economics, 88(1), 19-31. 
Drexler, A., Fischer, G. \& Schoar, A.S. (2010). Keeping it Simple: Financial Literacy and Rules of Thumb, CEPR Discussion Papers, 7994.

Frison L., \& Pocock, S.J. (1992) Repeated measures in clinical trials: analysis using mean summary statistics and its implications for design. Statistics in Medicine, 11(13), 1685-704.

Hall, B., \& Khan, B. (2003). Adoption of New Technology. NBER Working Paper No. 9730.

Ichinowski, C., Shaw, K. \& Prennushi, G. (1997). The effects of human resource management practices on productivity: A study of steel finishing lines. American Economic Review, 87 (3), 291-313.

Iddrisu, A. (2007). Cluster-based industrial development: The case of Suame Magazine vehicle repairs and metal work cluster in Ghana. Ph.D. Dissertation, the National Graduate Institute for Policy Studies, Tokyo.

Iddrisu, A., Mano, Y., \& Sonobe, T. (2011). Entrepreneurial Skills and Industrial Development: The Case of a Car Repair and Metalworking Cluster in Ghana. Journal of the Knowledge Economy, forthcoming.

Imbens, G. \& Angrist, J.D. (1994). Identification and estimation of Local Average Treatment Effects. Econometrica, 62 (2), 467-475.

Karlan, D. \& Valdivia, M. (2011). Teaching entrepreneur: Impact of business training on microfinance clients and institutions. Review of Economics and Statistics, 93 (2), 510-527.

Kennedy, L. (1999). Cooperating for survival: Tannery pollution and joint action in the Palar Valley (India). World Development, 27 (9), 1673-91.

Lazear, E. P. (2000). Performance Pay and Productivity. American Economic Review, 90(5), 1346-61.

McCormick, D. (1999). African enterprise clusters and industrialization. World Development, 27 (9), 1531-51. 
McKenzie, David. (2011). Beyond baseline and follow-up: the case for more $t$ in experiments. Policy Research Working Paper Series, 5639, The World Bank.

Mead, D.D., \& Lieadholm, C. (1998). The dynamics of micro and small enterprises in developing countries. World Development, 24 (3), 481-487.

Nadvi, K.(1999). Collective efficiency and collective failure: Response of the Sialkot surgical industrial cluster to global quality pressures. World Development, 27 (9),1605-26.

Nadvi, K. \& Schmitz, H. (1994). Industrial clusters in less developed countries: Review of experiences and research agenda. IDS Discussion Paper, 339. Institute of Development Studies, University of Sussex, Brighton.

Ruan, J. \& Zhang, X. (2009). Finance and cluster-based industrial development in China. Economic Development and Cultural Change, 58 (1), 143-164.

Schmitz, H. (1999). Global competition and local cooperation: Success and failure in the Sinos Valley, Brazil. World Development, 27 (9), 1627-50.

Schmitz, H. \& Nadvi, K. (1999). Clustering and Industrialization. World Development, 27, $1503-1514$.

Sonobe, T., Akoten, J., \& Otsuka, K. (2009). An Exploration into the successful development of the leather-shoe industry in Ethiopia. Review of Development Economics, 13 (4), 719-36.

Sonobe, T., Akoten, J. \& Otsuka, K. (2011). Growth process of informal enterprises in SubSaharan Africa: A case study of a metalworking cluster in Nairobi. Small Business Economics, 36 (3), 323-335.

Sonobe, T. \& Otsuka, K. (2006). Cluster-Based Industrial Development: An East Asian Model. Basingstoke: Palgrave Macmillan.

Sonobe, T. \& Otsuka, K. (2011). Cluster-Based Industrial Development: A Comparative 
Study of Asia and Africa. Basingstoke: Palgrave Macmillan.

Syverson, C. (2011). What determines productivity? Journal of Economic Literature, 49 (2), 326-365.

Tewari, M. (1999). Successful adjustment in Indian industry: The case of Ludhiana's woolen knitwear cluster. $\quad$ World Development, 27 (9), 1651-71.

Tybout, J. R. (2000). Manufacturing firms in developing countries: How well do they do, and why? Journal of Economic Literature, 38(1), 11-44. 
Table 1. Estimates of Enterprise Population in the Suame Magazine Cluster by Sector

\begin{tabular}{lcccc}
\hline & Garages & $\begin{array}{c}\text { Metalworking } \\
\text { enterprises }\end{array}$ & Others & Total \\
\hline 2000 & 4,958 & 807 & 2,204 & 7,969 \\
2002 & 6,222 & 990 & 2,618 & 9,830 \\
2003 & 7,847 & 1139 & 2,844 & 11,830 \\
\hline
\end{tabular}

Notes. These estimates are taken from the database of the Suame branch of the Ghana National Association of Garages (GNAG). Estimates do not include ancillary trades such as restaurants and telecommunication shops. "Others" include truck body builders, pot makers, sign writers, and some types of welders. 
Table 2. Characteristics of the sample entrepreneurs

\begin{tabular}{lcccc}
\hline & \multicolumn{3}{c}{ Treatment group } & Control \\
\cline { 2 - 4 } No. of entrepreneurs & Total & Participants & Refusers & Group \\
Male (\%) & 47 & 41 & 6 & 66 \\
Age (as of 2004) & 100 & 100 & 100 & 100 \\
From Ashanti (\%) & 45.4 & 44.2 & 53.6 & 44.8 \\
Years of schooling & 78.7 & 75.6 & 100 & 86.4 \\
Apprentice training (\%) & 10.4 & 10.4 & 10.4 & 10.3 \\
Years of operation (as of 2004) & 13.4 & 12.2 & 21.6 & 14.2 \\
Machinists (\%) & 91.5 & 92.7 & 83.3 & 67.9 \\
\hline
\end{tabular}

$\overline{\text { Notes. Treatment group refers to the group of entrepreneurs who were invited to the training program. }}$ 
Table 3. Percentages of firms adopting recommended practices and their business outcomes by treatment status, 2000 - 2008

\begin{tabular}{|c|c|c|c|c|c|}
\hline & $\begin{array}{l}\text { Treatment } \\
\text { (1) }\end{array}$ & $\begin{array}{l}\text { Control } \\
\text { (2) }\end{array}$ & & $\begin{array}{c}\text { Treatment } \\
\text { (3) }\end{array}$ & $\begin{array}{l}\text { Control } \\
\text { (4) }\end{array}$ \\
\hline \multicolumn{3}{|c|}{ Visiting customers (\%) } & \multicolumn{3}{|c|}{ Sales revenues $(1,000 \mathrm{GHS})$} \\
\hline 2000 & 19.2 & 12.2 & 2000 & 83.9 & 93.0 \\
\hline 2002 & 19.2 & 13.7 & 2002 & 72.1 & 66.5 \\
\hline 2004 & 20.3 & 13.7 & 2004 & 60.5 & 50.0 \\
\hline 2008 & 51.1 & 21.2 & 2008 & 47.6 & 30.4 \\
\hline \multicolumn{3}{|c|}{ Keeping business records (\%) } & \multicolumn{3}{|c|}{ Value added (1,000 GHS) } \\
\hline 2000 & 23.4 & 19.7 & 2000 & 53.9 & 67.3 \\
\hline 2002 & 23.4 & 19.7 & 2002 & 42.0 & 46.9 \\
\hline 2004 & 27.7 & 24.3 & 2004 & 37.2 & 32.3 \\
\hline 2008 & 63.8 & 30.3 & 2008 & 30.7 & 31.1 \\
\hline \multicolumn{3}{|c|}{ Analyzing business records (\%) } & \multicolumn{3}{|c|}{ Gross profit (1,000 GHS) } \\
\hline 2000 & 14.9 & 12.1 & 2000 & 44.6 & 49.2 \\
\hline 2002 & 14.9 & 15.2 & 2002 & 34.1 & 34.3 \\
\hline 2004 & 21.3 & 15.2 & 2004 & 30.0 & 23.9 \\
\hline 2008 & 55.3 & 18.2 & 2008 & 27.2 & 17.0 \\
\hline
\end{tabular}

Note: Sales revenue, value added, and gross profit are in terms of the 2008 constant GHS, obtained by using the GDP deflator taken from IMF's World Economic Outlook. 
Table 4. Real equipment investment before and after the training program (GHS)

\begin{tabular}{ccccccc}
\hline & \multicolumn{3}{c}{ Fabricators } & & Machinists & \\
\cline { 2 - 7 } & $\begin{array}{c}\text { Treatment } \\
(1)\end{array}$ & $\begin{array}{c}\text { Control } \\
(2)\end{array}$ & $\begin{array}{c}p \text {-value } \\
(3)\end{array}$ & $\begin{array}{c}\text { Treatment } \\
(4)\end{array}$ & $\begin{array}{c}\text { Control } \\
(5)\end{array}$ & $\begin{array}{c}p \text {-value } \\
(6)\end{array}$ \\
\hline 2006 & 154.8 & 40.5 & 0.276 & 197.3 & 487.2 & 0.386 \\
2007 & 108.1 & 39.5 & 0.263 & 258.1 & 299.6 & 0.201 \\
2008 & 135.5 & 217.6 & 0.621 & 905.0 & 174.4 & 0.047 \\
\hline
\end{tabular}


Table 5. The IV estimates of the linear probability model of survival

\begin{tabular}{|c|c|c|c|c|c|}
\hline & (i) & (ii) & (iii) & (iv) & (v) \\
\hline Instrumented $D_{i}$ & $\begin{array}{c}0.0951 * * * \\
(0.037)\end{array}$ & $\begin{array}{c}0.0868 * * \\
(0.035)\end{array}$ & $\begin{array}{c}0.0912 * * \\
(0.036)\end{array}$ & $\begin{array}{c}0.0880 * * \\
(0.035)\end{array}$ & $\begin{array}{c}0.0903 * * \\
(0.036)\end{array}$ \\
\hline Lagged visiting customers & --- & $\begin{array}{l}0.0362 \\
(0.025)\end{array}$ & $\begin{array}{l}0.0309 \\
(0.026)\end{array}$ & $\begin{array}{l}0.0346 \\
(0.025)\end{array}$ & $\begin{array}{l}0.0337 \\
(0.025)\end{array}$ \\
\hline Lagged record keeping & --- & $\begin{array}{c}0.0905 * * \\
(0.042)\end{array}$ & $\begin{array}{c}0.0884 * * \\
(0.039)\end{array}$ & $\begin{array}{c}0.0911^{* *} * \\
(0.040)\end{array}$ & $\begin{array}{c}0.0896 * * \\
(0.040)\end{array}$ \\
\hline Lagged record analysis & -- & $\begin{array}{l}-0.0248 \\
(0.039)\end{array}$ & $\begin{array}{r}-0.0359 \\
(0.038)\end{array}$ & $\begin{array}{l}-0.0316 \\
(0.038)\end{array}$ & $\begin{array}{r}-0.0349 \\
(0.038)\end{array}$ \\
\hline Lagged sales revenue & --- & --- & $\begin{array}{l}-0.0003 \\
(0.000)\end{array}$ & --- & --- \\
\hline Lagged value added & --- & --- & -- & $\begin{array}{c}-0.0002 \\
(0.000)\end{array}$ & --- \\
\hline Lagged gross profit & --- & --- & --- & -- & $\begin{array}{c}-0.0005 \\
(0.000)\end{array}$ \\
\hline Machinist & $\begin{array}{l}0.0209 \\
(0.043)\end{array}$ & $\begin{array}{l}0.0048 \\
(0.043)\end{array}$ & $\begin{array}{l}0.0185 \\
(0.051)\end{array}$ & $\begin{array}{l}0.0140 \\
(0.051)\end{array}$ & $\begin{array}{l}0.0200 \\
(0.049)\end{array}$ \\
\hline Age & $\begin{array}{l}0.0021 \\
(0.001)\end{array}$ & $\begin{array}{l}0.0020 \\
(0.001)\end{array}$ & $\begin{array}{l}0.0019 \\
(0.001)\end{array}$ & $\begin{array}{l}0.0020 \\
(0.001)\end{array}$ & $\begin{array}{l}0.0020 \\
(0.001)\end{array}$ \\
\hline From Ashanti & $\begin{array}{c}-0.0272 \\
(0.023)\end{array}$ & $\begin{array}{c}-0.0227 \\
(0.025)\end{array}$ & $\begin{array}{l}-0.0225 \\
(0.025)\end{array}$ & $\begin{array}{l}-0.0210 \\
(0.025)\end{array}$ & $\begin{array}{c}-0.0201 \\
(0.024)\end{array}$ \\
\hline Years of schooling & $\begin{array}{c}-0.0184 * \\
(0.011)\end{array}$ & $\begin{array}{c}-0.0205^{*} \\
(0.011)\end{array}$ & $\begin{array}{c}-0.0178^{*} \\
(0.009)\end{array}$ & $\begin{array}{c}-0.0193 * \\
(0.010)\end{array}$ & $\begin{array}{c}-0.0183^{*} \\
(0.009)\end{array}$ \\
\hline Apprentice training & $\begin{array}{l}-0.0246 \\
(0.057)\end{array}$ & $\begin{array}{l}-0.0251 \\
(0.057)\end{array}$ & $\begin{array}{c}-0.0210 \\
(0.056)\end{array}$ & $\begin{array}{c}-0.0244 \\
(0.057)\end{array}$ & $\begin{array}{c}-0.0249 \\
(0.056)\end{array}$ \\
\hline Years of operation & $\begin{array}{l}0.0017 \\
(0.001)\end{array}$ & $\begin{array}{l}0.0019 \\
(0.001)\end{array}$ & $\begin{array}{l}0.0021 \\
(0.001)\end{array}$ & $\begin{array}{l}0.0020 \\
(0.001)\end{array}$ & $\begin{array}{l}0.0020 \\
(0.001)\end{array}$ \\
\hline Intercept & $\begin{array}{c}0.9840 * * * \\
(0.123) \\
\end{array}$ & $\begin{array}{c}0.9731 * * * \\
(0.127)\end{array}$ & $\begin{array}{c}0.9927 * * * \\
(0.121)\end{array}$ & $\begin{array}{c}0.9844 * * * \\
(0.122)\end{array}$ & $\begin{array}{c}0.9943 * * * \\
(0.117)\end{array}$ \\
\hline$R$-squared & 0.103 & 0.130 & 0.138 & 0.132 & 0.135 \\
\hline
\end{tabular}


Table 6. The IV estimates of the training effects on the participants in the larger sample (ANCOVA)

\begin{tabular}{|c|c|c|c|c|c|c|}
\hline & $\begin{array}{l}\text { Visiting customers } \\
\text { (i) }\end{array}$ & $\begin{array}{l}\text { Record keeping } \\
\text { (ii) }\end{array}$ & $\begin{array}{l}\text { Record analysis } \\
\text { (iii) }\end{array}$ & $\begin{array}{l}\text { Sales revenue } \\
\text { (iv) }\end{array}$ & $\begin{array}{l}\text { Value added } \\
\text { (v) }\end{array}$ & $\begin{array}{c}\text { Gross profit } \\
\text { (vi) }\end{array}$ \\
\hline \multirow{2}{*}{ Instrumented $D_{i}$} & $0.2442 * * *$ & $0.3543 * * *$ & $0.4220 * * *$ & 11.3451 & 8.9618 & 4.2305 \\
\hline & $(0.067)$ & $(0.071)$ & $(0.069)$ & $(13.602)$ & $(8.190)$ & $(7.835)$ \\
\hline \multirow[t]{2}{*}{ Average lagged $Y_{i}$} & $0.8268 * * *$ & $0.7372 * * *$ & $0.8185^{* * *}$ & 0.2247 & 0.0504 & 0.0634 \\
\hline & $(0.050)$ & $(0.052)$ & $(0.064)$ & $(0.150)$ & $(0.076)$ & $(0.096)$ \\
\hline \multirow[t]{2}{*}{ Machinist } & 0.0515 & $-0.1336^{*}$ & -0.0832 & 3.8699 & $16.3252 * *$ & $13.9937 *$ \\
\hline & $(0.065)$ & $(0.071)$ & $(0.066)$ & $(11.210)$ & $(7.431)$ & (7.183) \\
\hline \multirow[t]{2}{*}{ Foundry } & 0.0463 & $0.2356^{* *}$ & 0.1575 & 20.8639 & 23.5250 & 6.4294 \\
\hline & $(0.092)$ & $(0.110)$ & $(0.099)$ & $(41.747)$ & (18.849) & $(17.765)$ \\
\hline \multirow[t]{2}{*}{ Age } & -0.0022 & -0.0023 & -0.0017 & $-0.9824 * *$ & $-0.7391 * *$ & $-0.6837 * *$ \\
\hline & $(0.003)$ & $(0.003)$ & $(0.003)$ & $(0.499)$ & $(0.310)$ & $(0.308)$ \\
\hline \multirow[t]{2}{*}{ From Ashanti } & 0.0901 & $0.2317 * * *$ & $0.1904 * * *$ & -18.2328 & -9.1312 & -9.7587 \\
\hline & $(0.071)$ & $(0.062)$ & $(0.065)$ & $(21.287)$ & (13.129) & (12.619) \\
\hline \multirow[t]{2}{*}{ Years of schooling } & $0.0127 *$ & -0.0004 & -0.0034 & $-5.7568 * *$ & -2.6470 & -2.5289 \\
\hline & $(0.007)$ & $(0.013)$ & $(0.012)$ & $(2.719)$ & (1.818) & $(1.831)$ \\
\hline \multirow[t]{2}{*}{ Apprentice training } & 0.0157 & -0.1306 & -0.0275 & -19.9928 & -12.6750 & -13.8110 \\
\hline & $(0.079)$ & $(0.099)$ & $(0.084)$ & $(21.403)$ & (17.657) & (17.924) \\
\hline \multirow[t]{2}{*}{ Years of operation } & 0.0040 & 0.0001 & -0.0003 & -0.3699 & -0.2386 & -0.1934 \\
\hline & $(0.003)$ & $(0.003)$ & $(0.003)$ & $(0.549)$ & $(0.288)$ & $(0.275)$ \\
\hline \multirow[t]{2}{*}{ Intercept } & -0.1174 & 0.2585 & 0.0920 & $161.2306^{* * *}$ & $93.3041 * *$ & $89.9934 * *$ \\
\hline & $(0.177)$ & $(0.217)$ & $(0.198)$ & $(60.084)$ & $(43.315)$ & $(44.054)$ \\
\hline$R$-squared & 0.503 & 0.474 & 0.518 & 0.194 & 0.174 & 0.127 \\
\hline
\end{tabular}

Notes. The number of observations is $139 . \quad$ Numbers in parentheses are $t$-statistics based on robust standard errors. $*, * *$, and $* * *$ indicate statistical significance at the 10 percent, 5 percent, and 1 percent levels, respectively. 
Table 7. The IV estimates of the training effects on the participants in the smaller sample (ANCOVA)

\begin{tabular}{|c|c|c|c|c|c|c|}
\hline & $\begin{array}{l}\text { Visiting customers } \\
\text { (i) }\end{array}$ & $\begin{array}{l}\text { Record keeping } \\
\text { (ii) }\end{array}$ & $\begin{array}{l}\text { Record analysis } \\
\text { (iii) }\end{array}$ & $\begin{array}{l}\text { Sales revenue } \\
\text { (iv) }\end{array}$ & $\begin{array}{c}\text { Value added } \\
(\mathrm{v})\end{array}$ & $\begin{array}{c}\text { Gross profit } \\
\text { (vi) }\end{array}$ \\
\hline Instrumented $D_{i}$ & $\begin{array}{l}0.2861 * * * \\
(0.084)\end{array}$ & $\begin{array}{c}0.3703 * * * \\
(0.080)\end{array}$ & $\begin{array}{c}0.3944 * * * \\
(0.081)\end{array}$ & $\begin{array}{l}17.8675 \\
(12.208)\end{array}$ & $\begin{array}{c}13.8858 * \\
(8.339)\end{array}$ & $\begin{array}{l}13.4647 * \\
(7.974)\end{array}$ \\
\hline$R$-squared & 0.496 & 0.534 & 0.540 & 0.140 & 0.145 & 0.134 \\
\hline \multicolumn{7}{|l|}{$\begin{array}{l}\text { Heterogeneous effects } \\
\text { (1) line of business }\end{array}$} \\
\hline Instrumented $D_{i}$ & $\begin{array}{c}0.2254^{*} \\
(0.126)\end{array}$ & $\begin{array}{c}0.5527 * * * \\
(0.141)\end{array}$ & $\begin{array}{l}0.4507 * * * \\
(0.137)\end{array}$ & $\begin{array}{l}16.4637 \\
(14.111)\end{array}$ & $\begin{array}{l}8.9997 \\
(9.079)\end{array}$ & $\begin{array}{l}9.6859 \\
(8.987)\end{array}$ \\
\hline Instrumented (machinist $\times D_{i}$ ) & $\begin{array}{c}0.099 \\
(0.159)\end{array}$ & $\begin{array}{l}-0.300^{*} \\
(0.176)\end{array}$ & $\begin{array}{l}-0.093 \\
(0.174)\end{array}$ & $\begin{array}{c}2.318 \\
(21.551)\end{array}$ & $\begin{array}{c}8.052 \\
(14.916)\end{array}$ & $\begin{array}{c}6.242 \\
(14.404)\end{array}$ \\
\hline \multicolumn{7}{|l|}{ (2) age } \\
\hline Instrumented $D_{i}$ & $\begin{array}{c}0.7521 * * \\
(0.338)\end{array}$ & $\begin{array}{l}0.4705 \\
(0.339)\end{array}$ & $\begin{array}{l}0.9757 * * * \\
(0.298)\end{array}$ & $\begin{array}{l}40.2946 \\
(63.628)\end{array}$ & $\begin{array}{l}49.1621 \\
(38.980)\end{array}$ & $\begin{array}{l}49.6076 \\
(37.765)\end{array}$ \\
\hline Instrumented (age $\times D_{i}$ ) & $\begin{array}{l}-0.0106 \\
(0.008)\end{array}$ & $\begin{array}{r}-0.0023 \\
(0.008)\end{array}$ & $\begin{array}{c}-0.0132 * \\
(0.007)\end{array}$ & $\begin{array}{l}-0.5085 \\
(1.298)\end{array}$ & $\begin{array}{l}-0.8012 \\
(0.737)\end{array}$ & $\begin{array}{l}-0.8201 \\
(0.714)\end{array}$ \\
\hline \multicolumn{7}{|l|}{ (3) years of schooling } \\
\hline Instrumented $D_{i}$ & $\begin{array}{r}-0.2289 \\
(0.242)\end{array}$ & $\begin{array}{r}-0.3797 \\
(0.410)\end{array}$ & $\begin{array}{r}-0.3419 \\
(0.375)\end{array}$ & $\begin{array}{c}66.8643 * \\
(38.697)\end{array}$ & $\begin{array}{c}45.1309^{*} \\
(23.470)\end{array}$ & $\begin{array}{l}49.6244 * * \\
(22.966)\end{array}$ \\
\hline Instrumented (schooling $\times D_{i}$ ) & $\begin{array}{c}0.0507 * * \\
(0.023) \\
\end{array}$ & $\begin{array}{c}0.0735^{*} \\
(0.040) \\
\end{array}$ & $\begin{array}{c}0.0722 * * \\
(0.036) \\
\end{array}$ & $\begin{array}{l}-4.8034 \\
(3.216) \\
\end{array}$ & $\begin{array}{c}-3.0635^{*} \\
(1.853) \\
\end{array}$ & $\begin{array}{c}-3.5459^{*} \\
(1.832) \\
\end{array}$ \\
\hline
\end{tabular}

Notes. The number of observations is 113 . Numbers in parentheses are $t$-statistics based on robust standard errors. *, **, and *** indicate statistical significance at the 10 percent, 5 percent, and 1 percent levels, respectively. Although not reported here, these regressions controlled for the machinist dummy, age of the entrepreneur, the Ashanti dummy, years of schooling, experience of apprentice training, and the number of years of operation of the firm. 
Table 8. Bounds for the IV estimates of the effect of the training program on the participants (ANCOVA)

\begin{tabular}{|c|c|c|c|c|c|c|}
\hline & $\begin{array}{l}\text { Visiting customers } \\
\text { (i) }\end{array}$ & $\begin{array}{c}\text { Record keeping } \\
\text { (ii) }\end{array}$ & $\begin{array}{c}\text { Record analysis } \\
\text { (iii) }\end{array}$ & $\begin{array}{l}\text { Sales revenue } \\
\text { (iv) }\end{array}$ & $\begin{array}{c}\text { Value added } \\
(\mathrm{v})\end{array}$ & $\begin{array}{c}\text { Gross profit } \\
\text { (vi) }\end{array}$ \\
\hline \multicolumn{7}{|l|}{ Approach I } \\
\hline \multirow[t]{2}{*}{ Lower bound } & 0.0560 & $0.1587 *$ & $0.1558 *$ & -10.5153 & -3.5338 & -4.6008 \\
\hline & $(0.092)$ & $(0.086)$ & $(0.090)$ & $(13.736)$ & $(9.081)$ & $(8.958)$ \\
\hline \multirow[t]{2}{*}{ Upper bound } & $0.3226 * * *$ & $0.4187 * * *$ & $0.4210 * * *$ & $27.9109 * *$ & $18.7591 * *$ & $17.9136 * *$ \\
\hline & $(0.082)$ & $(0.082)$ & $(0.082)$ & $(12.848)$ & $(8.268)$ & $(8.048)$ \\
\hline \multicolumn{7}{|l|}{ Approach II } \\
\hline \multirow[t]{2}{*}{ Lower bound } & $0.2444 * * *$ & $0.3184 * * *$ & $0.3507 * * *$ & 18.6051 & 13.1175 & 12.9273 \\
\hline & $(0.082)$ & $(0.080)$ & $(0.081)$ & $(12.682)$ & $(8.196)$ & (7.986) \\
\hline \multirow[t]{2}{*}{ Upper bound } & $0.2969 * * *$ & $0.3758 * * *$ & $0.4008 * * *$ & $22.8463 *$ & $15.3746^{*}$ & $15.0786^{*}$ \\
\hline & $(0.082)$ & $(0.081)$ & $(0.082)$ & $(12.726)$ & $(8.205)$ & $(7.997)$ \\
\hline \multicolumn{7}{|l|}{ Approach III } \\
\hline \multirow[t]{2}{*}{ Lower bound } & $0.2602 * * *$ & $0.3356^{* * *}$ & $0.3657 * * *$ & 19.8774 & $13.7946^{*}$ & $13.5727^{*}$ \\
\hline & $(0.081)$ & $(0.080)$ & $(0.081)$ & $(12.690)$ & $(8.195)$ & $(7.986)$ \\
\hline \multirow[t]{2}{*}{ Upper bound } & $0.2812 * * *$ & $0.3586 * * *$ & $0.3858 * * *$ & $21.5740 *$ & $14.6974 *$ & $14.4333^{*}$ \\
\hline & $(0.082)$ & $(0.081)$ & $(0.081)$ & $(12.707)$ & $(8.199)$ & $(7.991)$ \\
\hline
\end{tabular}

Notes.
The number of observations is 136 for the bounds analyses. Numbers in parentheses are $t$-statistics based on robust standard errors. *,**, and *** indicate statistical significance at the 10 percent, 5 percent, and 1 percent levels, respectively. Although not reported here, these regressions controlled for the machinist dummy, age of the entrepreneur, the Ashanti dummy, years of schooling, experience of apprentice training, and the number of years of operation of the firm. 